\title{
Gaya Pengambilan Keputusan pada Profesi Account Officer di Industri Perbankan ditinjau dari Sikap Terhadap Resiko dan Orientasi Pelanggan
}

\author{
ROSATYANI PUSPITA ADIATI
}

Departemen Psikologi Industri dan Organisasi, Fakultas Psikologi Universitas Airlangga

\begin{abstract}
ABSTRAK
Pertimbangan rasional perlu dimiliki oleh account officer ketika mereka memutuskan untuk menyetujui atau menolak proposal kredit pelanggan. Sebagai bagian dari profesi marketing, seorang account officer harus melayani pelanggan dengan baik yang diwujudkan dengan mengucurkan kredit kepada customer. Berdasarkan itu, menarik untuk melihat bagaimana account officer menggunakan gaya pengambilan keputusan tertentu berdasarkan pada sikap risiko dan orientasi terhadap pelanggan. Tiga skala yang terdiri dari dua sub-skala orientasi risiko, skala orientasi pelanggan penjual, dan lima sub-skala gaya pengambilan keputusan diberikan kepada 138 pekerja berprofesi account officer dari perbankan swasta. Analisis data menggunakan teknik korelasi kanonik menunjukkan bukti bahwa ada korelasi yang signifikan antara sikap terhadap risiko dan orientasi pelanggan dengan gaya pengambilan keputusan. Sikap menghindari risiko dan orientasi pelanggan berkorelasi positif dengan pengambilan keputusan yang rasional. Sikap kecenderungan mengambil risiko berkorelasi positif dengan pengambilan keputusan intuitif. Penghindaran risiko dan kecenderungan mengambil risiko berkorelasi positif dengan tipe pengambilan keputusan dependant. Penghindaran risiko berkorelasi positif dengan pengambilan keputusan tipe avoidant. Kecenderungan mengambil risiko berkorelasi positif, dimana orientasi pelanggan berkorelasi negatif, dengan pengambilan keputusan spontan. Hasil dari penelitian ini memiliki beberapa implikasi praktis, seperti dapat digunakan pertimbangan kriteria pemilihan account officer, atau meningkatkan program pelatihan untuk petugas akun untuk meningkatkan penggunaan analisis rasional.
\end{abstract}

Kata kunci: gaya pengambilan keputusan, orientasi pelanggan, sikap terhadap resiko

\begin{abstract}
For those who work as account officer, they need to have rational considerations when they decide to approve or reject a customer's credit proposal. As part of the marketing profession, an account officer must serve customers well which is realized by approving credit proposal to customers. Based on that, it is interesting to see how account officers use certain decision-making styles based on risk attitudes and customer orientation. Three scales consisting of two risk orientation subscales, the customer orientation scale, and five decision-making style subscales were given to 138 workers who were account officers from private banking. Data analysis using canonical correlation techniques shows evidence that there is a significant correlation between attitudes toward risk and customer orientation with decisionmaking styles. Risk aversion and customer orientation are positively correlated with rational decision making. The tendency to take risks is positively correlated with intuitive decision making. Risk aversion and risk taking tendencies are positively correlated with dependent decision-making types. Risk aversion is positively correlated with avoidant type decision making. Risk-taking trends are positively correlated, where customer orientation is negatively correlated, with spontaneous decision making. The
\end{abstract}


results of this study have several practical implications, such as can be used to consider account officer selection criteria, or improve training programs for account officers to increase the use of rational analysis.

Key words: decision making style, customer orientation, risk attitude

INSAN Jurnal Psikologi dan Kesehatan Mental, 2018, Vol. 3(1), 31-43, doi: 10.20473/jpkm.v3i12018.31-43 Dikirimkan: 22 Oktober 2018 Diterima: 31 Oktober 2018 Diterbitkan: 8 November 2018

Editor: Rizqy Amelia Zein

*Alamat korespondensi: Fakultas Psikologi Universitas Airlangga, Jl. Airlangga 4 -6 Surabaya. Pos-el: rosatyani.adiati@psikologi.unair.ac.id

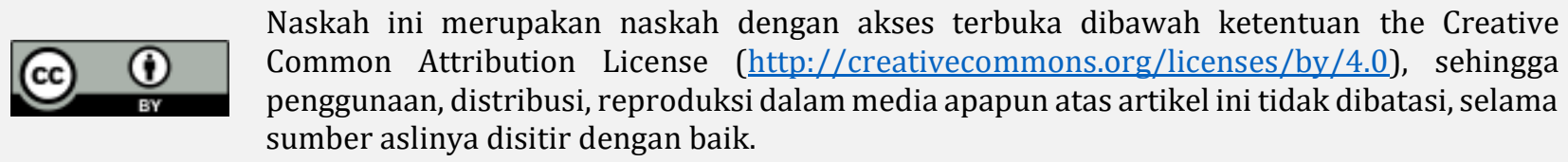

\section{PEN D A H U L U A N}

Adair (2007) menyatakan bahwa pengambilan keputusan adalah proses menentukan tindakan yang akan diambil dan biasanya melibatkan beberapa pilihan. Objek proses pengambilan keputusan biasanya adalah solusi, jawaban, atau kesimpulan. Pavić (2008) juga menyatakan bahwa pengambilan keputusan adalah proses yang menjadi ciri manusia dan semua organisasi. Tanpa keputusan, organisasi tidak akan mampu beradaptasi, berevolusi, dan melakukan aktivitas bisnis. Pengambilan keputusan adalah tugas dasar yang melibatkan karyawan untuk kegiatan organisasi. Berbagai definisi proses pengambilan keputusan dapat ditemukan dalam literatur, dan begitu banyak penelitian, tetapi kebanyakan dari mereka menyatakan bahwa pengambilan keputusan adalah proses berkelanjutan yang membutuhkan waktu, membutuhkan persiapan dan pengetahuan yang signifikan.

French, dkk. (2009) menyatakan bahwa ada beberapa faktor yang mempengaruhi proses pengambilan keputusan. Faktor pertama berkaitan dengan konteks masalah, yang meliputi bagaimana struktur masalah, potensi ketidakpastian, urgensi keputusan, dan pilihan yang tersedia. Faktor kedua adalah faktor kognitif yang terdiri dari keyakinan dan pengetahuan pembuat keputusan, sikap terhadap risiko, nilai dan preferensi, perhitungan yang mereka lakukan, urgensi pribadi dari keputusan, dan berapa banyak pilihan yang mereka miliki. Faktor ketiga adalah konteks sosial, seperti siapa pembuat keputusan, berapa banyak pengambil keputusan yang terlibat, siapa pemangku kepentingan, siapa yang memiliki kewenangan atas sumber daya yang diperlukan, apa tanggung jawab dan akuntabilitas para pengambil keputusan, dan sebagainya.

Schermerhorn, dkk. (2002) menyatakan bahwa di lingkungan saat ini, masalah yang dihadapi pengambil keputusan organisasi tampaknya semakin kompleks. Tren tempat kerja berikut ini yang mempengaruhi proses pengambilan keputusan adalah bisnis menjadi lebih kecil dalam ukuran, sehingga mereka melakukan lebih banyak outsourcing dan mempekerjakan lebih sedikit pekerja penuh waktu. Lenbih lanjut, ada beberapa bentuk organisasi baru, lebih fleksibel, dan mudah beradaptasi menggantikan struktur piramida tradisional. Pemahaman multifungsi semakin penting karena organisasi menekankan koordinasi lateral, pekerja dengan pengetahuan teknis dan keterampilan tim menjadi semakin dicari, dan sifat "pekerjaan" berubah ketika pekerjaan berubah cepat, membutuhkan pembelajaran berkelanjutan, dan kurang terikat oleh waktu kerja tradisional. 
Scott dan Bruce (1995) dalam Rehman, dkk. (2012) menyatakan bahwa ada lima jenis gaya pengambilan keputusan, terdiri dari; (a) rational decision making, dengan ciri-ciri adanya pemahaman menyeluruh untuk evaluasi logis dari berbagai alternatif; (b) intuitive decision making; yang dicirikan oleh kepercayaan pada firasat dan perasaan; (c) dependant decision making, yang dicirikan dengan mencari nasehat dan arahan dari orang lain; (d) avoidant decision making, yang dicirikan oleh usaha untuk menghindari dalam membuat keputusan; dan (e) spontaneous decision making, yang dicirikan dengan mengambil keputusan secara tiba-tiba dan impulsif.

Dalam industri perbankan, Proenca dan Castro (2002) menyatakan bahwa ada faktor-faktor yang mempengaruhi pengambil keputusan paling banyak, yaitu tekanan untuk mendapatkan keuntungan, yang mempengaruhi evaluasi dan struktur pembayaran, dan tingkat formalisasi proses pengambilan keputusan. Proenca dan Castro (2002) mengatakan bahwa lingkungan yang kompetitif dalam industri perbankan membuat mereka harus meningkatkan manajemen mereka dan mempertahankan hubungan pelanggan.

Hubungan mereka dengan pelanggan akan mempengaruhi karyawan perbankan dalam memberikan layanan kepada pelanggan mereka. Hubungan perbankan-pelanggan juga dipengaruhi oleh tingkat perputaran perusahaan, norma kredit dan wewenang terbatas, dan struktur organisasi (Pervien, dkk. dalam Proenca \& Castro, 2002). Penelitian oleh Proenca dan Castro (2002) juga menemukan beberapa poin yang terkait dengan perilaku dan hubungan nasabah-perbankan. Hubungan antara perbankan dan mereka dipengaruhi oleh pola interaksi, persepsi manajer mereka, biaya transaksi, kemampuan bernegosiasi, kondisi keuangan dan ekonomi pelanggan, serta persepsi dan sikap mereka terhadap risiko transaksi.

Weber (2003) dalam Shafi, dkk. (2011) menyatakan bahwa sikap risiko adalah hasil dari persepsi risiko. Beberapa orang melihat risiko sebagai sesuatu yang menarik dan mengikat untuk mencari keuntungan dari situasi yang berisiko. Di sisi lain, beberapa orang lebih suka menghindari situasi berisiko dan mencari posisi yang lebih aman untuk menghindari kerugian. Hillson dan Webster (2005) juga menyatakan bahwa preferensi individu dalam menghadapi kondisi berisiko tergantung pada diri mereka sendiri dan dari tanggapan mereka terhadap pengalaman mereka, bagaimanapun, lingkungan manusia memiliki pengaruh yang signifikan terhadap persepsi mereka tentang ambiguitas. Dyer dan Sarin (1982) dalam Weber dkk (2002) mengusulkan "sikap risiko relatif" untuk mengidentifikasi peran pengambilan risiko individu yang relatif konstan. Risiko yang mereka hadapi adalah variabel yang dapat ditafsirkan berbeda untuk setiap orang, sebagai fungsi konteks dan kontennya. Komposisi preferensi ini menghasilkan pilihan dan perilaku individu yang berbeda pada kondisi yang berisiko (Weber \& Milliman, 1997 dalam Weber, dkk., 2002).

Penelitian pada konteks tenaga penjualan menunjukkan bukti bahwa tenaga penjual yang efektif bekerja lebih cerdas daripada lebih keras dan memberlakukan seperangkat perilaku yang sesuai meningkatkan kemungkinan pencapaian tujuan (Singh \& Koshy 2008). Singh \& Koshy (2008) menyatakan bahwa tujuan akhir orientasi pelanggan dari seorang penjual bukan hanya untuk lebih memahami kebutuhan dan preferensi pelanggan tetapi untuk akhirnya mencapai tujuan melayani kebutuhan tersebut dengan menjual produk dan layanan perusahaan mereka. Singh \& Koshy (2008) mendefinisikan orientasi pelanggan sebagai tingkat di mana dia mempraktekkan konsep pemasaran dengan mencoba membantu pelanggannya membuat keputusan pembelian yang akan memuaskan kebutuhan pelanggan. Singh \& Koshy (2008) juga mengidentifikasi tujuh karakteristik orientasi pelanggan penjual, yaitu; (a) keinginan untuk membantu pelanggan membuat keputusan pembelian yang memuaskan; (b) membantu pelanggan menilai kebutuhan mereka; (c) menawarkan produk yang akan memuaskan kebutuhan tersebut; (D) menjelaskan produk secara akurat; (e) mengadaptasi presentasi penjualan agar sesuai dengan minat pelanggan; (f) menghindari tipuan taktik yang menipu atau manipulatif; dan (g) menghindari penggunaan tekanan tinggi. 
Berdasarkan literatur tersebut, penelitian ini bertujuan untuk memahami bagaimana gaya pengambilan keputusan di antara orang-orang yang bekerja sebagai account officer, berdasarkan pada sikap terhadap risiko dan orientasi pelanggan yang mereka miliki.

\section{MET O D E}

\section{Desain Penelitian}

Penelitian ini dilakukan dengan menggunakan pendekatan kuantitatif untuk melakukan uji korelasional antar variabel. Desain penelitian adalah survei cross-sectional, sedangkan teknik pengambilan data yang digunakan dalam penelitian ini adalah kuesioner self-report.

\section{Partisipan}

Partisipan dari penelitian ini adalah 138 orang yang bekerja sebagai account officer pada bank swasta di Indonesia. Semua partisipan penelitian ini adalah para account officer yang pernah melakukan booking aplikasi kredit setelah mereka menyetui proposal kredit dari customer. Pengambilan data diawali dengan informed consent yang menyatakan seluruh partisipan bersedia mengisi data sesuai kondisi riil dan berpartisipasi dalam penelitian ini.

\section{Pengukuran}

Pengukuran penelitian ini terdiri dari tiga skala Likert, masing-masing mengukur sikap terhadap risiko partisipan, mengukur orientasi pelanggan, dan gaya pengambilan keputusan. Skala sikap terhadap risiko diadaptasi dari Risk Attitude Questionnaire (ROQ) dari Rohrmann (2002). Orientasi pelanggan diukur dengan skala Sales Orientation-Customer Orientation (SOCO) yang diadopsi dari Singh dan Koshy (2008). Gaya pengambilan keputusan diukur dengan pengambilan keputusan umum dari Sylvie and Huang (2008).

Kelima skala gaya pengambilan keputusan, dua skala sikap terhadap risiko dan skala orientasi pelanggan memiliki rentang 1 hingga 5, dimana skor 1 artinya responden merasa item tersebut sangat tidak sesuai dengan dirinya dan skor 5 menunjukkan responden merasa item tersebut sangat sesuai dengan dirinya. Skor yang lebih tinggi menunjukkan dukungan yang lebih besar terhadap variabel. Koefisien Cronbach's alpha untuk setiap variabel menunjukkan bukti pengukuran yang dapat diandalkan (0.776 untuk rational, 0.793 untuk intuitive, 0.786 untuk dependant, 0.658 untuk avoidant, 0.803 untuk spontaneous, 0.699 untuk sikap menghindari risiko, 0.676 untuk sikap mengambil Resiko dan 0.609 untuk orientasi pelanggan).

\section{Analisis Data}

Teknik analisis data pada penelitian ini adalah korelasi dan regresi linier. Analisis korelasi kanonik berusaha untuk mengidentifikasi dan mengukur asosiasi antara dua set variabel. Analisis korelasi kanonik berfokus pada korelasi antara kombinasi linear dari variabel dalam satu set dan kombinasi linear dari variabel dalam set lain. Idenya adalah pertama untuk menentukan pasangan kombinasi linier yang memiliki korelasi terbesar. Kemudian, kami menentukan pasangan kombinasi linier yang memiliki korelasi terbesar di antara semua pasangan yang tidak berkorelasi dengan pasangan yang dipilih sebelumnya, dan seterusnya. Pasangan kombinasi linear disebut variabel kanonis, dan korelasinya disebut korelasi kanonik (Johnson \& Wichern, 2007). Korelasi kanonik membutuhkan pengujian asumsi data, yang terdiri dari uji linearitas antara dua set variabel, normalitas multivariat, dan tidak ada

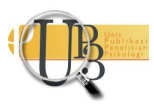


multikolinieritas di antara variabel-variabel tersebut. Teknik analisis data dilakukan dengan bantuan program SPSS (Statistical Package for the Social Sciences) versi 17.0.

\section{HAS IL PENELITIAN}

\section{Analisis Korelasi Kanonikal}

Uji Wilks menunjukkan bahwa ada fungsi kanonikal antara variabel dependen dan independen yang signifikan yang ditunjukkan oleh nilai Uji Pillais, Hotellings, Wilks dan Roy, yang hasilnya signifikan pada taraf nyata 0.05 . Kemudian kita melihat eigenvalue dan korelasi kanonik, dan pemuatan kanonik untuk setiap set variabel sebelum menemukan pemuatan kanonikal silang seperti yang dijelaskan di bawah ini.

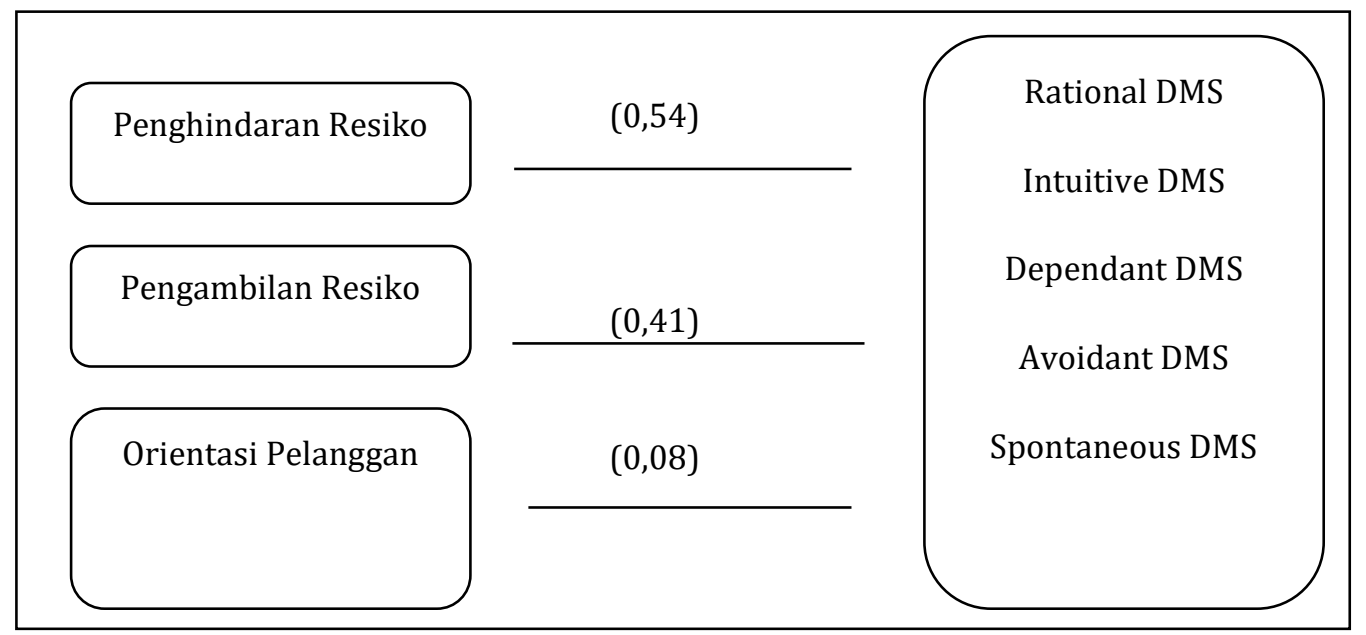

Gambar 1. Hasil Uji Korelasi Kanonik

Dari perhitungan pemuatan lintas kanonik, hasilnya menunjukkan bahwa sikap menghindari risiko memiliki muatan kanonikal ke gaya pengambilan keputusan yang lebih besar daripada sikap mengambil risiko dan orientasi pelanggan. Namun, efek penghindaran risiko, kecenderungan risiko dan orientasi pelanggan penjual pada setiap jenis gaya pengambilan keputusan akan dijelaskan di bawah ini.

Dari hasil analisis yang diperoleh, diperoleh adanya korelasi yang bermakna antara variabel dependen dan variabel independen. Komponen variabel dependen yang paling dominan adalah rational decision making dibandingkan dengan variabel dependen yang lainnya. Sedangkan untuk komponen variabel independen yang paling dominan adalah sikap menghindari resiko. Korelasi antarvariabel yang kuat terjadi pada kelompok variabel sebagai berikut: (a) variabel sikap menghindari resiko memiliki nilai korelasi paling besar ( $r=0.87$ ) dengan variabel decision making style; (b) variabel dependant memiliki korelasi paling besar $(r=0.70)$ dengan kelompok variabel sikap menghindari resiko, sikap mengambil resiko, dan orientasi pelanggan; (c) variabel sikap menghindari resiko memiliki nilai korelasi paling besar ( $r=0.54)$ dengan variabel dependant.

\section{Analisis regresi}


Analisis regresi dalam perhitungan kanonikal yang dilakukan memperoleh hasil sebagai berikut; (a) variabel sikap menghindari resiko dan orientasi pelanggan secara signifikan memiliki pengaruh positif terhadap rational decision-making style; (b) variabel sikap mengambil resiko secara signifikan memiliki pengaruh positif terhadap intuitive decision-making style; (c) variabel sikap menghindari resiko dan sikap mengambil resiko secara signifikan memiliki pengaruh positif terhadap dependant decision making style; (d) variabel sikap menghindari resiko secara signifikan memiliki pengaruh positif terhadap avoidant decision making style; (e) variabel sikap mengambil resiko secara signifikan memiliki pengaruh positif terhadap variabel spontaneous decision making style, sedangkan variabel orientasi pelanggan secara signifikan memiliki pengaruh negatif terhadap variabel spontaneous decision making style.

Tabel 1. Parameter Prediktor Rational Decision Making dalam Model Regresi (N=138)

\begin{tabular}{lccccc}
\hline \multicolumn{1}{c}{ Prediktor } & B & B & SE & t & Nilai p \\
\hline Risk aversion & 0.23 & 0.33 & 0.06 & 3.92 & $.000^{*}$ \\
Risk propensity & 0.07 & 0.09 & 0.07 & 1.05 & .297 \\
Orientasi pelanggan & 0.13 & 0.38 & 0.03 & 4.65 & $.000^{*}$ \\
\hline
\end{tabular}

*nilai $\mathrm{p}<.05$

Berdasarkan Tabel 1, maka dapat dilihat bahwa variabel risk aversion $(B=0.23, S E=0.06$, nilai $\mathrm{p}<.001)$ dan orientasi pelanggan $(B=0.13, S E=0.03$, nilai $\mathrm{p}<.001)$ berkorelasi positif terhadap rational decision making, sedangkan risk propensity $(B=0.07, S E=0.07$, nilai $\mathrm{p}=.297)$ diketahui tidak berkaitan secara substansial dengan rational decision making.

Tabel 2. Parameter Prediktor Intuitive Decision Making dalam Model Regresi ( $\mathrm{N}=138)$

\begin{tabular}{lccccc}
\hline \multicolumn{1}{c}{ Prediktor } & B & $\boldsymbol{\beta}$ & SE & t & Nilai p \\
\hline Risk aversion & 0.11 & 0.12 & 0.08 & 1.33 & .184 \\
Risk propensity & 0.29 & 0.29 & 0.09 & 3.19 & $.002^{*}$ \\
Orientasi pelanggan & 0.02 & 0.04 & 0.04 & 0.47 & .636 \\
\hline
\end{tabular}

*nilai $\mathrm{p}<.05$

Berdasarkan Tabel 2, maka dapat dilihat bahwa variabel risk aversion $(B=0.11, S E=0.08$, nilai $\mathrm{p}=.184)$ dan orientasi pelanggan $(B=0.02, S E=0.04$, nilai $\mathrm{p}=.636)$ tidak berkorelasi signifikan dengan intuitive decision making, sedangkan risk propensity $(B=0.29, S E=0.09$, nilai $\mathrm{p}=.002)$ diketahui berkorelasi positif, namun lemah dengan intuitive decision making.

Tabel 3. Parameter Prediktor Dependant Decision Making dalam Model Regresi ( $\mathrm{N}=138)$

\begin{tabular}{lccccc}
\hline \multicolumn{1}{c}{ Prediktor } & B & $\boldsymbol{\beta}$ & SE & t & Nilai p \\
\hline Risk aversion & 0.24 & 0.30 & 0.07 & 3.55 & $.001^{*}$ \\
Risk propensity & 0.25 & 0.27 & 0.08 & 3.25 & $.001^{*}$ \\
Orientasi pelanggan & -0.03 & -0.07 & 0.03 & -0.82 & .412 \\
\hline
\end{tabular}

*nilai $\mathrm{p}<.05$

Berdasarkan Tabel 3, maka dapat dilihat bahwa variabel risk aversion $(B=0.24, S E=0.07$, nilai $\mathrm{p}=.001)$ dan risk propensity $(B=0.25, S E=0.08$, nilai $\mathrm{p}=.001)$ berkorelasi positif dan signifikan dengan dependant decision making, sedangkan orientasi pelanggan $(B=-0.03, S E=0.03$, nilai $\mathrm{p}=.412)$ diketahui berkorelasi negatif, namun sangat lemah dengan dependant decision making.

INSAN Jurnal Psikologi dan Kesehatan Mental

2018, Vol. 3(1), 31-43

doi: 10.20473/jpkm.v3i12018.31-43

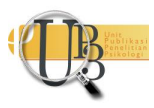


Tabel 4. Parameter Prediktor Avoidant Decision Making dalam Model Regresi (N=138)

\begin{tabular}{lccccc}
\hline \multicolumn{1}{c}{ Prediktor } & B & $\boldsymbol{\beta}$ & SE & t & Nilai p \\
\hline Risk aversion & 0.33 & 0.35 & 0.08 & 3.98 & $.000^{*}$ \\
Risk propensity & 0.14 & 0.13 & 0.09 & 1.47 & .143 \\
Orientasi pelanggan & -0.06 & -0.13 & 0.04 & -1.50 & .136 \\
\hline *nilai p<.05 & & & & &
\end{tabular}

Berdasarkan Tabel 4, maka dapat dilihat bahwa variabel orientasi pelanggan $(B=-0.06, S E=0.04$, nilai $\mathrm{p}=.136)$ dan risk propensity $(B=0.14, S E=0.09$, nilai $\mathrm{p}=.143)$ tidak berkorelasi dengan avoidant decision making, sedangkan risk aversion $(B=0.33, S E=0.09$, nilai $\mathrm{p}<.001)$ diketahui berkorelasi positif, namun cenderung kecil dengan avoidant decision making.

Tabel 5. Parameter Prediktor Spontaneous Decision Making dalam Model Regresi (N=138)

\begin{tabular}{lccccc}
\hline \multicolumn{1}{c}{ Prediktor } & B & $\boldsymbol{\beta}$ & SE & t & Nilai p \\
\hline Risk aversion & -0.19 & -0.17 & 0.10 & -1.94 & .054 \\
Risk propensity & 0.47 & 0.37 & 0.11 & 4.24 & $.000^{*}$ \\
Orientasi pelanggan & -0.13 & -0.26 & 0.04 & -3.00 & $.003^{*}$ \\
\hline
\end{tabular}

*nilai $\mathrm{p}<.05$

Berdasarkan Tabel 5, maka dapat dilihat bahwa variabel orientasi pelanggan $(B=-0.13, S E=0.04$, nilai $\mathrm{p}=.003)$ dan risk propensity $(B=0.47, S E=0.11$, nilai $\mathrm{p}<.001)$ berkorelasi dengan spontaneous decision making, sedangkan risk aversion $(B=-0.19, S E=0.10$, nilai $\mathrm{p}=.054)$ diketahui berkorelasi negatif, namun sangat lemah dengan spontaneous decision making.

\section{I S K U S I}

Berdasarkan tulisan Hablemitoglu dan Yildirim (2008), rational decision-making style merupakan pengambilan keputusan yang secara logis terkait dengan tujuan. Rational decision-making style memiliki kontribusi positif pada kinerja organisasi, terutama apabila dikaitkan dengan tugas-tugas yang membutuhkan ketepatan, keajegan, efisiensi, dan disiplin (Allinson \& Hayes, 1996 dalam SarmanySchuller, 2010). Penelitian oleh Sarmany-Schuller (2010) juga menunjukkan bahwa individu yang memiliki gaya pengambilan keputusan berdasarkan analisis lebih individual dan lebih berhasil dalam tugas-tugas dalam jangka panjang dan tugas yang membutuhkan analisis secara detail dalam permasalahan yang spesifik.

Pernyataan yang bertentangan dengan pendapat diatas diungkapkan oleh Zhong (2005), bahwa pendekatan rasional dalam pengambilan keputusan juga memiliki bahaya tersendiri, terutama karena pendekatan rasional cenderung mengabaikan peran emosi ketika berada dalam situasi yang membutuhkan pertimbangan moral, etika, dan empati. Penelitian oleh Zhong (2005) juga menyatakan bahwa penggunaan rational decision-making style memiliki kontribusi terhadap perilaku-perilaku yang tidak etis seperti kecurangan, permasalahan komunikasi, dan permasalahan lain terkait etika.

AO di Bank X memiliki tugas yang menuntut kemampuan analisis yang tinggi dan ketepatan dalam melakukan pengambilan keputusan. Oleh sebab itu, gaya pengambilan keputusan rasional merupakan gaya yang cukup dominan digunakan dalam bidang pekerjaan AO. Hal ini sejalan dengan penelitian dari Schuller (2010) yang menemukan hasil bahwa pekerja dengan gaya pengambilan keputusan analitisrasional cenderung mampu menunjukkan kinerja yang baik dan fokus dalam bidang pekerjaan yang membutuhkan analisis secara mendalam dan penyelesaian permasalahan secara mendetail.




Kesesuaian pendekatan rational decision-making style dengan karakteristik pekerjaan seorang pekerjaan AO terletak pada kebutuhan untuk melakukan analisis mendalam sebelum memutuskan kelayakan nasabah dalam menerima kredit. Sikap untuk menghindari risiko, yang disebut dengan sikap menghindari resiko merupakan satu faktor yang mendukung seseorang untuk menggunakan gaya pengambilan keputusan rasional. Pegawai yang memiliki sikap penghindaran untuk melakukan hal-hal yang berisiko cenderung akan bersikap hati-hati, menilai situasi secara spesifik dan mengikuti prosedur dan cara kerja yang aman dalam melakukan pekerjaannya sehingga hasil yang diharapkan bisa tercapai sesuai dengan rencana. Orientasi pelanggan juga memiliki pengaruh dalam memunculkan pengambilan keputusan secara rasional. Pegawai yang memiliki orientasi pelanggan yang tinggi akan cenderung mencari informasi dan menawarkan produk yang benar-benar sesuai dengan kebutuhan dan kemampuan nasabahnya. Dengan adanya penggunaan produk yang sesuai dengan kebutuhan dan kemampuan nasabah, maka dapat menghasilkan kerjasama jangka panjang yang lancar dan sehat.

Orientasi pelanggan yang tinggi menghindarkan pegawai dari melakukan rekomendasi yang terlalu instan atau hanya bertujuan memenuhi target, namun tidak sesuai dengan kebutuhan dan kemampuan nasabah saat itu. Dengan mempertimbangkan kondisi nasabah, maka pegawai akan mampu mengambil keputusan yang logis supaya tujuan pekerjaannya dapat tercapai dengan baik. Hasil penelitian ini senada dengan penelitian oleh Bone (2006) yang menjelaskan bahwa faktor reputasi pelanggan, penilaian terhadap keamanan dan kebutuhan pelanggan, dan ketaatan prosedur akan mempengaruhi seorang tenaga pemasaran dalam memutuskan apakah ia akan menerima atau menolak calon customernya. Berdasarkan hal tersebut, dapat dikatakan bahwa semakin besar sikap menghindari resiko atau sikap menghindari risiko dan orientasi pelanggan yang dimiliki pegawai, maka akan mempengaruhi semakin besarnya gaya pengambilan keputusan rasional yang digunakan dalam pekerjaannya.

Berdasarkan Robbins (2003), intuitive decision-making adalah proses pengambilan keputusan yang tidak disadari oleh pelaku, yang didasarkan pengalaman-pengalaman sebelumnya. Scott dan Bruce (1995, dalam Hablemitoglu \& Yildirim, 2008) menyatakan bahwa pengambilan keputusan intuitif dilakukan berdasarkan pengalaman. Keputusan yang intuitif melibatkan fokus pada kesadaran diri secara emosional, dan minim dalam melibatkan pencarian informasi atas hal yang akan datang maupun pertimbangan-pertimbangan alternatif lainnya. Intuitive decision-making style memiliki kontribusi dalam performa individu dan organisasi, terutama dalam pelaksanaan tugas-tugas yang yang membutuhkan pendekatan umum kepada masalah, membutuhkan ide dan brainstorming atas solusi, serta membutuhkan kerjasama dengan pihak lain, seperti misalnya pada sales, marketing, maupun tugas-tugas yang membutuhkan pengamatan terhadap pola-pola yang tidak terstruktur. Pengambilan keputusan secara intuitif juga lebih efektif untuk mendukung tugas-tugas yang membutuhkan pertimbangan secara menyeluruh dalam waktu yang relatif singkat.

Berdasarkan penelitian Schuller (2010) nampak bahwa pada pekerjaan yang berhubungan dengan orang lain, intuitive decision-making style memberikan kontribusi bagi performa secara lebih baik daripada rational decision-making style. Hal ini disebabkan individu yang memiliki intuitive decisionmaking style mampu melibatkan perasaan, memiliki respon yang baik atas permasalahan yang muncul, dan berani secara aktif mengambil tindakan yang mereka yakini akan membawa efek positif meskipun belum menemukan penguatan yang bisa dijelaskan secara detail. Penggunaan intuitive decision-making style pada bidang pekerjaan yang sesuai dengan karakteristik diatas akan mampu memaksimalkan performance yang ingin diraih, baik oleh individu maupun organisasi.

Pada bidang pemasaran, intuisi sering kali merupakan hal yang berpengaruh dalam aktivitas mereka. Intuisi muncul disebabkan pengalaman dan proses belajar, sehingga mereka mampu mengenali pola ketika menghadapi suatu permasalahan, sehingga menghasilkan keputusan yang tampak cepat didasarkan pada pemahaman besar ketika menghadapi sebuah situasi. Sejalan dengan penelitian Schuller (2010), profesi marketing yang membutuhkan kemampuan untuk berhubungan dengan orang

INSAN Jurnal Psikologi dan Kesehatan Mental

2018, Vol. 3(1), 31-43

doi: 10.20473/jpkm.v3i12018.31-43 
lain akan dapat dimaksimalkan melalui intuitive decision-making style. Sikap mengambil resiko merupakan sikap untuk berani menerima risiko. Kecenderungan seseorang untuk memiliki keterbukaan terhadap risiko disebabkan mereka melihat risiko sebagai peluang untuk berhasil (Weber, dkk., 2002). Ketika seorang pegawai dengan sikap mengambil resiko yang tinggi menghadapi sebuah situasi berisiko, ia akan melihat situasi tersebut mengandung peluang untuk menghasilkan keuntungan, meskipun secara logis situasi tersebut cenderung tidak menguntungkan.

Pegawai yang memiliki sikap mengambil resiko tinggi akan berani mengambil kemungkinan terkecil untuk berhasil, meskipun situasi tersebut memiliki kemungkinan gagal lebih besar. Berkaitan dengan profesi sebagai tenaga pemasaran di jabatan AO, kecenderungan untuk mengambil risiko tentunya akan dihubungkan dengan kepribadian dan masa kerja sebelumnya. Sebagai tenaga pemasar, mereka terbiasa untuk mengambil risiko tertentu untuk mencapai hasil yang diharapkan, misalnya pencapaian target. Situasi yang kompetitif mendukung mereka untuk dapat mengambil risiko dan mencari peluang untuk dapat mencapai hasil yang diharapkan. Tidak jarang mereka menemukan situasi yang mereka yakini kebenarannya, namun kurang bisa dijelaskan secara logis. Keyakinan mereka atas peluang keberhasilan yang diraih didasarkan atas pengalaman-pengalaman sebelumnya yang memberikan banyak informasi mengenai sebuah situasi serupa. Hal tersebut menjelaskan bagaimana pegawai dengan sikap mengambil resiko yang tinggi cenderung lebih banyak menggunakan intuisi untuk mendukung keputusan yang akan diambil.

Pada proses pengambilan keputusan berdasarkan intuisi, perasaan dan kepercayaan subyektif individu berdasarkan proses belajar dan pengalaman sebelumnya lebih ber peran dominan daripada pertimbangan detail mengenai kondisi saat itu. Dengan demikian, dapat dikatakan bahwa intuisi memiliki peran besar dalam pengambilan keputusan pada individu yang memiliki kecenderungan mengambil risiko, dengan tujuan mampu mengambil keputusan yang tepat atas situasi yang dihadapi. Hasil penelitian ini senada dengan penelitian dari Khatri dan Ng (2000), yang menyatakan bahwa pengambilan keputusan intuitif banyak dilakukan di lingkungan yang tidak stabil dan memiliki informasi yang terbatas untuk dianalisis.

Berdasarkan hasil penelitian ini, terdapat pengaruh positif sikap mengambil resiko pada intuitive decision-making style. Dengan mengacu pada pembahasan diatas, maka dapat diterima bahwa semakin tinggi kecenderungan pegawai untuk mengambil risiko, maka hal tersebut akan memacunya untuk semakin besar dalam menggunakan gaya pengambilan keputusan berdasarkan intuisi yang dimiliki ketika menghadapi situasi-situasi yang ada dalam pekerjaan mereka.

Dependant decision-making style merupakan gaya pengambilan keputusan dimana seseorang cenderung membutuhkan dukungan dari orang lain ketika harus mengambil keputusan (Scott \& Bruce, 1995 dalam Rehman, dkk., 2010). Dependant decision-making terkait dengan kesiapan seseorang untuk menerima konsekuensi atas keputusan yang dihasilkannya. Ketidakmampuan seseorang untuk mengambil keputusan bisa disebabkan oleh faktor situasional seperti kurangnya informasi, maupun faktor individu seperti kurangnya kepercayaan diri dan pesimisme (French, dkk., 2009). Ketika seseorang merasa tidak yakin dengan keputusan yang akan diambilnya, ia akan menghadapi konflik dan mencari tindakan yang dapat dilakukan untuk mengatasi tekanan, salah satunya ia akan cenderung mencari dukungan dari rekan kerja atau seseorang yang dipercayanya lebih mampu.

Pengaruh dependant decision-making style terhadap performa organisasi memiliki dua sisi, baik kontribusi positif dan negatif. Russ, dkk. (1996) menyatakan bahwa individu yang memiliki dependant decision making style memiliki karakteristik penggunaan saran dan dukungan dari orang lain dalam mengambil keputusan. Seseorang yang memiliki nilai tinggi dalam dimensi memberikan tanggungjawab yang mereka miliki kepada orang lain. Ketika perilaku ini dipandang sebagai sikap partisipatif, maka akan menghasilkan reaksi positif baik dari bawahan maupun atasan seseorang. Sebaliknya, jika perilaku ini dilihat sebagai sikap ketergantungan kepada orang lain, maka ia bisa menghasilkan reaksi negatif 
dari lingkungan kerja pegawai yang bersangkutan. Berdasarkan penelitian dari Russ, dkk. (1996), sales manager yang memiliki karakteristik pengambilan keputusan secara cepat dan berhati-hati memiliki performance yang lebih baik dibandingkan mereka yang memiliki karakter menunda atau menghindari pengambilan keputusan.

Penelitian ini menunjukkan adanya pengaruh positif dari sikap menghindari resiko dan sikap mengambil resiko pada dependant decision-making style, yang bisa diartikan bahwa ketika seseorang memiliki peningkatan dalam sikap menghindari risiko maupun mengambil risiko, maka hal tersebut akan memacu semakin tinggi gaya pengambilan keputusan dependant yang dimilikinya. Gaya pengambilan keputusan dependant banyak digunakan karena berkaitan dengan kompleksitas situasi dan informasi yang terbatas, yang menjadikan lingkungan kerja pada jabatan AO relatif tidak stabil. Ketidakstabilan lingkungan ini kebanyakan disebabkan oleh banyaknya interaksi dengan orang lain (nasabah), informasi dan pertimbangan prosedur yang sangat banyak, serta tekanan untuk mencapai target.

Melalui gaya pengambilan keputusan dependant, baik individu dengan sikap menghindari resiko dan sikap mengambil resiko yang tinggi akan berusaha mencari dukungan dari orang lain ketika ia harus mengambil sebuah keputusan, dengan tujuan mencari penguatan atas keputusan yang akan diambilnya. Dengan mencari saran dan dukungan dari orang lain, maka diharapkan penilaian individu atas risiko mampu dipertanggungjawabkan secara tepat dan memberikan hasil yang diharapkan. Tingginya skor penggunaan dependant decision-making dalam penelitian ini juga terkait dengan proses pengambilan keputusan atas aktivitas para partisipan, khususnya yang berkaitan dengan pengambilan keputusan atas pengajuan pinjaman kredit oleh nasabah. Pada aktivitas ini AO tidak bekerja sendirian untuk memutuskan diterima atau tidaknya pengajuan nasabah kredit, tetapi melalui komite kredit yang minimal terdiri dari: AO (pegawai bersangkutan), Team Leader di Kantor Cabang atau Cabang Pembantu (Capem) dan Kepala Cabang atau Capem tersebut.

Apabila ada salah satu posisi yang kosong, maka untuk memenuhi kuorum maka pengambilan keputusan kredit harus melalui Area Business Manager atau Area Manager. Berdasarkan situasi tersebut, maka dependant decision-making style merupakan salah satu gaya pengambilan keputusan yang cukup banyak digunakan dalam aktivitas pekerjaan seorang Account officer.

Avoidant decision-making style merupakan upaya yang dilakukan seorang individu untuk menunda, menghindari dan menolak diri dari situasi yang mewajibkannya untuk membuat keputusan (Scott \& Bruce, 1995 dalam Rehman, 2010). Gaya pengambilan keputusan secara avoidant inimunculberdasarkan perasaan individu mengenai control yang dimilikinya dalam menghadapi permasalahan (Philips, dkk., 1984 dalam Spicer \& Sadler-Smith, 2005). Individu yang memiliki gaya pengambilan keputusan avoidant biasanya menghindarkan diri dari kewajiban membuat keputusan, sampai akhirnya mereka benar-benar terpaksa memutuskan sesuatu. Gaya pengambilan keputusan avoidant ini dipengaruhi baik faktor kognisi, faktor situasional, maupun emosi yang dimiliki individu (French, dkk., 2009).

Apabila dikaitkan dengan lingkungan bekerja yang dialami partisipan, seringkali mereka berhadapan dengan situasi yang memaksa mereka untuk mengambil keputusan dalam situasi berisiko, yaitu ketika mereka diminta untuk memberikan rekomendasi mengenai kelayakan pengajuan kredit nasabah. Tidak jarang mereka harus memberikan toleransi atas informasi yang bertentangan atau tidak lengkap, dikarenakan target yang tinggi dan terbatasnya nasabah yang potensial. Berdasarkan French, dkk. (2009), ketika menghadapi pilihan yang sulit dan berisiko, individu akan menghadapi konflik, yang akan mempengaruhi baik kondisi emosional maupun strategi keputusan yang akan digunakan.

Tekanan untuk membuat keputusan dan mengubah emosi negatif ini secara bersamaan bisa menghasilkan reaksi berupa defensive avoidance, yaitu mengurangi konflik dengan cara mendistorsi informasi dengan cara menonjolkan aspek positif atau mengurangi aspek negatif, maupun mengabaikan

INSAN Jurnal Psikologi dan Kesehatan Mental

2018, Vol. 3(1), 31-43

doi: 10.20473/jpkm.v3i12018.31-43

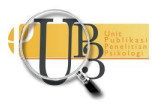


konflik yang muncul, menghilangkan informasi yang bertentangan dan melakukan penundaan terhadap penyelesaian masalah. Pada penelitian ini, ditemukan pengaruh positif sikap menghindari resiko pada avoidant decision-making style.

Berdasarkan hal tersebut dapat dikatakan bahwa semakin seseorang memiliki kecenderungan bersikap hati-hati atau menghindari risiko, hal tersebut akan menyebabkan ia memiliki kecenderungan yang makin tinggi untuk melakukan penghindaran atas pengambilan keputusan. Hal ini dapat dijelaskan melalui mekanisme bahwa ketika seorang pegawai memiliki kecenderungan untuk menghindari risiko (sikap menghindari resiko), akan semakin membuatnya melakukan penghindaran atas membuat keputusan atas permasalahan yang dihadapinya. Hal ini disebabkan memiliki keinginan yang tinggi untuk berada di zona aman, sehingga hal-hal yang memiliki efek yang belum jelas (seperti pengambilan keputusan dalam situasi berisiko) akan membuatnya merasa tidak aman.

Penghindaran dalam membuat keputusan ini akan semakin jelas ketika ada kepentingan yang bertentangan untuk dapat menunjukkan kinerja optimal melalui pencapaian target berupa pencairan kredit. Hal ini disebabkan dalam aktivitas sebagai AO, risiko dalam merekomendasikan kelayakan nasabah untuk pemberian kredit merupakan hal yang pasti ada, meskipun dapat diminimalisasi melalui pertimbangan yang matang dan prinsip kehati-hatian. Individu yang memiliki avoidant decision-making style yang terlalu tinggi, dikhawatirkan akan banyak membuang kesempatan untuk bisa melakukan penjualan dikarenakan kekhawatiran berlebih atas risiko. Hal ini tentu akan berdampak negatif terhadap performa yang dimilikinya, seperti misalnya tidak dapat mencapai target yang diharapkan seperti yang menjadi latar belakang permasalahan dalam penelitian ini.

Spontaneous decision-making memiliki karakteristik pengambilan keputusan dalam suatu situasi dilakukan secara tiba-tiba dan impulsif (Scott \& Bruce, 1995 dalam Rehman, 2010). Karakteristik lainnya adalah dilakukannya pengambilan keputusan dalam waktu yang relatif singkat (Sylvie, 2007). Spontaneous decision making style bisa memberikan pengaruh positif apabila digunakan dalam aktivitas yang membutuhkan pengambilan keputusan yang tepat. Sebaliknya, untuk tipe aktivitas yang membutuhkan analisis mendalam dan detail, pengambilan keputusan secara spontan dikhawatirkan akan kurang sesuai dan menimbulkan kekhawatiran terjadi bias.

Untuk tipe pekerjaan yang membutuhkan analisis secara mendalam, spontaneous decision-making style bisa menghasilkan keputusan yang terburu-buru sehingga tidak tepat sasaran. Terkait dengan latar belakang penelitian, di mana aktivitas dari AO yang sangat membutuhkan analisis dan pemahaman yang menyeluruh ketika menghadapi calon nasabah, maka spontaneous decision-making style tidak terlalu sesuai untuk diterapkan. Hal ini disebabkan AO sebaiknya melakukan telaah secara luas terhadap calon nasabah. Analisis secara mendalam ini membutuhkan waktu yang cukup banyak. Spontaneous decisionmaking style yang memiliki karakteristik kecepatan dalam mengambil keputusan tidak sejalan dengan prinsip kehati-hatian yang harus dilakukan oleh AO dalam melakukan analisis.

Penelitian ini menunjukkan ada pengaruh positif sikap mengambil resiko yang merupakan kecenderungan untuk mengambil dan menerima risiko terhadap spontaneous decision-making style, sebaliknya orientasi pelanggan terbukti berpengaruh secara negatif terhadap spontaneous decisionmaking style. Ada pun penjelasan mengenai temuan ini adalah sebagai berikut. Pada pegawai yang memiliki sikap mengambil resiko yang tinggi, mereka cenderung untuk mengambil risiko yang muncul sebagai salah satu upaya mendapatkan peluang keberhasilan. Sebaliknya, seorang pegawai marketing yang memiliki orientasi pelanggan yang tinggi, ia akan memberikan usaha lebih untuk dapat memastikan pelanggan yang dihadapinya berhasil menggunakan produknya secara tepat. Ketika seseorang memiliki kecenderungan untuk berani mengambil risiko, maka ia cenderung akan bertindak secara cepat ketika muncul peluang. Sebaliknya, ketika seseorang memiliki orientasi kepada pelanggan yang tinggi, maka ia cenderung mengumpulkan informasi terkait dengan kebutuhan dan pelanggan 
tersebut sebelum memutuskan penjualan produknya, yang akan berpengaruh terhadap rendahnya spontaneous decision-making style yang dimilikinya

\section{S I M P U L A N}

Berdasarkan temuan penelitian, maka dapat ditarik kesimpulan bahwa terdapat hubungan yang bermakna antara risk attitude, orientasi pelanggan dan decision making style. Hal itu diindikasikan dari adanya korelasi positif sikap menghindari resiko dan orientasi pelanggan pada rational decision-making style. Korelasi positif juga ditemukan dalam sikap mengambil resiko pada intuitive decision-making style, sikap menghindari resiko dan sikap mengambil resiko pada dependant decision-making style, sikap menghindari resiko pada avoidant decision-making style, serta sikap mengambil resiko pada spontaneous decision-making style. Sedangkan orientasi pelanggan berpengaruh negatif pada spontaneous decision-making style.

Selanjutnya, kita harus mempertimbangkan bahwa setiap gaya pengambilan keputusan jenis memiliki efeknya sendiri terhadap kinerja organisasi. Penelitian dari Rehman (2012) untuk karyawan perbankan Turki menunjukkan bukti bahwa gaya pengambilan keputusan yang rasional, tergantung dan spontan berkorelasi positif dengan kinerja organisasi organisasi, sedangkan gaya pengambilan keputusan avoidant berkorelasi negatif dengan kinerja organisasi, dan gaya pengambilan keputusan intuitif tidak memiliki korelasi yang signifikan terhadap organisasi. kinerja. Hasilnya menunjukkan bahwa setiap jenis gaya pengambilan keputusan memiliki kontribusinya sendiri untuk kinerja organisasi, dan kita juga harus mempertimbangkan tentang budaya organisasi dan kebijakan manajemen. Karena itu, penting untuk memiliki penelitian lanjutan untuk memahami tentang gaya pengambilan keputusan dalam budaya Indonesia.

\section{U C A P A N T E R I MAKASIH}

Penulis berterimakasih kepada segenap direksi dan karyawan PT Bank Mega, Tbk yang telah memberikan dukungan data sehingga penelitian ini dapat terlaksana dan selesai dengan baik.

\section{PUSTAKA ACUAN}

Adair, J. E. (2007). Decision making and problem-solving strategies (Vol. 9). Philadelphia: Kogan Page Publishers.

Bone, S. A. (2006). To Accept or Reject a Customer's Business? the Interaction of Customer Quantitative Merit, Customer Reputation and the Decision-maker's Need for Discretion (Doctoral dissertation, Oklahoma State University).

French, S., Maule, J., \& Papamichail, N. (2009). Decision behaviour, analysis and support. Cambridge: Cambridge University Press.

Hablemitoglu, S., \& Yildirim, F. (2008). The relationship between perception of risk and decision making styles of Turkish university students: A descriptive study of individual differences. World Applied Sciences Journal, 4(2), 214-224.

Hillson, D., \& Murray-Webster, R. (2017). Understanding and managing risk attitude. London: Routledge.

Johnson, R.A., Wichern, D.W. (2007). Applied Multivariate Statistical Analysis. New Jersey. PearsonPrentice 
Khatri, N., \& Ng, H. A. (2000). The role of intuition in strategic decision making. Human relations, 53(1), 57-86.

Pavić, I. (2008). Nature of Managerial Decision Making Along the Continuum of the Decision Making Pyramid. The Business Review, Cambridge, 10(2).

Proença, J. F., \& de Castro, L. M. (2005). "Stress" in business relationships: a study on corporate bank services. International Journal of Bank Marketing, 23(7), 527-541.

Rehman, R. (2010). Decision Making Styles of Managers in Pakistan: Role of Management Status and Organization Sector. Institute of Interdisciplinary Business Research, 2(7).

Rehman, R. R., Khalid, A., \& Khan, M. (2012). Impact of employee decision making styles on organizational performance: in the moderating role of emotional intelligence. World Applied Sciences Journal, 17(10), 1308-1315.

Robbins, S.P. (2003). Organizational Behavior. New Jersey: Prentice Hall International Inc.

Rohrmann, B. (2002). Risk attitude scales: Concepts and questionnaires. Melbourne: University of Melbourne, 12. Diakses melalui http://www.rohrmannresearch.net/pdfs/rohrmann-rasreport.pdf.

Russ, F. A., McNeilly, K. M., \& Comer, J. M. (1996). Leadership, decision making and performance of sales managers: A multi-level approach. Journal of Personal Selling \& Sales Management, 16(3), 1-15.

Sarmany-Schuller, I. (2010). Decision Making Under Time Pressure in Regard to Preferred Cognitive Style (Analytical-Intuitive) and Study Orientation. Studia Psychologica, 52(4).

Schermerhorn, J.R., Hunt, J.G., \& Osborn, R.N. (2002). Organizational Behavior Seventh Edition. John Wiley \& Sons.Inc

Shafi, H., Akram, M., Hussain, M., Sajjad, S. I., \& Rehman, K. U. (2011). Relationship between risk perception and employee investment behavior. Journal of Economics and Behavioral Studies, 3(6), 345-351.

Singh, R., \& Koshy, A. (2008). Salesperson's Customer Orientation: A Reconceptualization and a New Definition. Indian Institute of Management. Ahmedabad: India.

Russ, F. A., McNeilly, K. M., \& Comer, J. M. (1996). Leadership, decision making and performance of sales managers: A multi-level approach. Journal of Personal Selling \& Sales Management, 16(3), 1-15.

Sylvie, G. (2007). Decision making by nordic newspaper editors. An exploratory study and comparison to US editors. JIBS: Jönköping.

Sylvie, G., \& Huang, J. S. (2008). Value systems and decision-making styles of newspaper front-line editors. Journalism \& Mass Communication Quarterly, 85(1), 61-82.

Weber, E. U., Blais, A. R., \& Betz, N. E. (2002). A domain-specific risk-attitude scale: Measuring risk perceptions and risk behaviors. Journal of Behavioral Decision Making, 15(4), 263-290.

Zhong, C.B. (2005). The Ethical Dangers of Rational Decision Making. Northwestern University. 